\title{
Factors determining the success of public private partnership projects in Nigeria
}

\author{
Afeez Olalekan Sanni \\ Bells University of Technology, Ota, Nigeria
}

\begin{abstract}
The implementation of public private partnership (PPP) procurement method is expected to help governments in the development of infrastructures and provides an opportunity for the reduction in the governments' debt profiles. This method has been adopted in Nigeria for more than a decade and with these years of implementation, few infrastructural projects have been developed using this method while some have been unsuccessful. This study aims to examine the PPP projects implementation in Nigeria and identify the most critical factors that could determine the success of such projects. A total of 184 questionnaires were received from public and private sectors' participants in the implementation of PPP projects. An exploratory factor analysis identified seven critical success factors as projects feedback, leadership focus, risk allocation and economic policy, good governance and political support, short construction period, favourable socio-economic factors, and delivering publicly needed service. This study shows that more developmental projects could be delivered through PPP if the government could focus on these main factors in the implementation process. The result will influence policy development towards PPP and guide the partners in the development of PPP projects.
\end{abstract}

Keywords: Developing countries, Nigeria, procurement, public private partnership, critical success factors.

Paper Type: Research article

\section{Introduction}

The governments are increasingly using public private partnership (PPP) procurement arrangement to deliver works and services in both developed and developing countries $(\mathrm{Ng}$, Wong and Wong, 2012; Li et al., 2005). Where the private sector is being used to providing public facilities through partnerships in order to address the infrastructural deficit without the financial commitment to the government (Syuhaida and Aminah, 2009). This method is adopted so that the limited available resources could be channelled to other sectors (Udechukwu, 2012). Despite the benefits, the utilization of PPP as a procurement option still remains comparatively low in percentage to the total public investments in infrastructure (RICS, 2011). However, the public sectors are looking towards best approaches in order to satisfy and meet the demand of the citizens despite the challenges of inadequate budgeting while the citizens are calling for improved public services (Hartmann, Davies and Frederiksen, 2010). This demand is very high in Nigeria which is the biggest economy in Africa (The Economist, 2014) and her high population of about 170 million needs to be supported by adequate public infrastructures.

The Global Competitiveness Report 2012-2013 ranked Nigeria as 117th in the quality of overall infrastructure highlighted in the twelve pillars of competitiveness among 144 countries across the

\footnotetext{
Copyright: Construction Economics and Building 2016. (C) 2016 Afeez Olalekan Sanni. This is an Open Access article distributed under the terms of the Creative Commons Attribution 4.0 Unported (CC BY 4.0) License (https://creativecommons.org/licenses/by/4.0/), allowing third parties to copy and redistribute the material in any medium or format and to remix, transform, and build upon the material for any purpose, even commercially, provided the original work is properly cited and states its license.
}

Citation: Sanni, A. O. 2016. Factors determining the success of public private partnership projects in Nigeria, Construction Economics and Building, 16(2), 42-55. DOI: http://dx.doi.org/10.5130/AJCEB.v16i2.4828

Corresponding author: Afeez Olalekan Sanni; Email - afeezsanni1@gmail.com

Publisher: University of Technology Sydney (UTS) ePress 
continents (World Economic Forum, 2012). The report showed that the government's investments in the provision of public infrastructures and other services in the country contributed very little to the development of the public facilities, and the implementation of PPP infrastructure projects has recorded very low performance in Nigeria (Awodele, Ogunlana and Akinradewo, 2012). This study sets out to examine the PPP projects implementation in Nigeria and to identify the most critical factors that determine the success of such projects. The findings of this study could help the industry practitioners to understand the important factors for PPP projects while providing valuable information for organizations that intend to participate in PPP projects in Nigeria. This study applies an industry-wide survey with large respondent numbers, to explore the key ingredients for successful delivery of PPP projects and to examine the perceptions of public and private sector participants. The findings of this study are valuable and useful for the successful application of PPP in the Nigerian construction industry.

\section{Literature review}

The critical success factors (CSFs) are those limited areas in the organization's activities that could result in the organization's success and performance (Kwak, Chih and Ibbs, 2009). It could also be defined as "few key areas of activity in which favourable results are absolutely necessary for a particular manager to reach his goals" (Bullen and Rockart, 1981, p3). The concept of critical success factors could be traced to Ronald Daniel, who initiated and used the word 'success factors' in the 1960s (Chien, 2014). This was later made popular by John F. Rockart of MIT Sloan School of Management in the 1970s where he introduced 'critical success factors' in the article published in Harvard Business Review (Bullen and Rockart, 1981; Chien, 2014). Since then, many authors have applied the idea to various fields. However, this is a concept being adopted in the construction industry (Sanvido et al., 1992; Chua, Cog and Loh, 1999). The concept of critical success factors has been investigated by many authors on PPP projects (Jefferies, Gameson and Rowlinson, 2002; Li et al., 2005; Cartligde, 2006; Jacobson and Choi, 2008; Cheung, 2009; Agrawal, 2010; Minnie, 2011; Chou et al., 2012; Ng, Wong and Wong, 2012; Cheung, Chan and Kajewski, 2012; Tang et al., 2013; Ismail, 2013; Wibowo and Alfen, 2014; and Ameyan and Chan, 2015). A comprehensive literature review was conducted to identify CSFs of PPP in the construction industry. Relevant published documents like textbooks, journal articles, conference papers, research reports and other materials were reviewed. Table 1 presents the summary of the literature review on the key PPP success factors identified by authors from different countries. The table listed fifteen (15) different studies by several authors that cut across various regions. The review identified twenty-eight (28) key success factors for PPP projects implementation. These success factors were later included in the questionnaire survey for this study.

The factors that were identified for the private sector participants in the implementation of PPP projects are strong private consortium (Jefferies, Gameson and Rowlinson, 2002; Li et al., 2005; Zhang, 2005; Cheung, 2009; Ng, Wong and Wong, 2012; and Ameyan and Chan, 2015), appropriate risk allocation and sharing (Li et al., 2005, Zhang, 2005; Cheung, 2009; Wibowo and Alfen, 2014), available financial market (Li et al., 2005; Cheung, Chan and Kajewski, 2012; Ismail, 2013; Ameyan and Chan, 2015), thorough and realistic cost/benefit assessment (Li et al., 2005 and Chou et al., 2012), economy viability (Zhang, 2005 and Ng, Wong and Wong, 2012), nature of contractual agreement (Zhang, 2005; Agrawal, 2010; and Wibowo and Alfen, 2014), favourable legal framework (Cheung, 2009; Cheung, Chan and Kajewski, 2012; Ismail, 2013, Wibowo and Alfen, 2014; and Ameyan and Chan, 2015), delivery publicly needed service (Minnie, 2001; Ng, Wong and Wong, 2012; and Ismail, 2013), sound economy policy (Cheung, 2009; and Ismail, 2013), and stable micro-economic conditions (Cheung, 2009; and Cheung et al, 2012). Two factors that were identified as key factors for the delivery of PPP projects by the public sector were the alignment with government's strategic objectives (Ng, Wong and Wong, 
2012; and Tang et al., 2013) and strong political support (Wibowo and Alfen, 2014; and Ameyan and Chan, 2015). However, the commitment and responsibility of public/private sectors ( $\mathrm{Li}$ et al., 2005; Cartlidge, 2006; Jacobson and Choi, 2008; Cheung 2009; Chou et al, 2012; Ismail, 2013; and Ameyan and Chan, 2015), true partnership (Cartlidge, 2006; Jacobson and Choi, 2008), and open communication (Cartlidge, 2006; Jacobson and Choi, 2008) are the factors that are common to both public and private sectors' participants in the projects' implementation.

Jefferies, Gameson and Rowlinson (2002) identified three key factors for Australia; solid consortium with a wealth of expertise, considerable experience, high profile and a good reputation; an efficient approval process that assists the stakeholders in a very tight timeframe; and innovation in the financing methods of the consortium. Tang et al. (2013) identified five key success factors as the identification of client/owner requirements; clear and precise briefing documents; feedback from completed projects; and thorough understanding of client/owner requirements. Thus, the wealth of expertise, experience, and reputation are expected to help in the successful delivery of projects under PPP arrangement. The expertise is expected to be in both public and private sectors of the industry. They both have great roles to play in the system. $\mathrm{Li}$ et al. (2005) also identified five key PPP success factors as: (1) strong private consortium; (2) appropriate risk allocation and risk sharing; (3) available financial market; (4) commitment/responsibility of public/private sectors; and (5) thorough and realistic cost/benefit assessment. Additionally, the commitment and shared vision, open communication and trust, and collaboration are the three key PPP success factors identified in the United States of America by Jacobson and Choi (2008), whereas, in China, the key success factors for PPP projects are a stable macro-economic condition; favourable legal framework; sound economic policy; available financial market; and multi-benefit objectives (Cheung, Chan and Kajewski, 2012). A stable macro-economic condition is seen as an important factor in the delivery of PPP project successfully in the country, although, China is still being recognized as a developing country, despite the large size of her economy. If the economic condition is stable, the investors would be willing to invest their money, since they hope to recoup their investment in a favourable economic environment. These factors are those identified in the countries that are regarded as developed nations. These factors are tending towards the private sector's wealth of experiences and the utilization of such experiences.

Agrawal (2010) identified concession agreement, short construction period, and repayment of the debt as the PPP success factors in India, while Minnie (2011) identified delivering a publicly needed service and achieving the objectives of the partnership for South Africa. Ameyan and Chan (2015) identified government (political) commitment, adequate financing, public acceptance/support, strong and competent private partner, and effective regulatory and legal structures. In Malaysia, Ismail (2013) identified five key success factors for the delivery of PPP projects; good governance; commitment/responsibility of public/private sectors; favourable legal framework; sound economic policy; and available financial market. While in Indonesia, the identified key success factors for PPP projects are sound legal basis; an irrevocable contract; sensible and manageable risk-sharing arrangements; clearly defined coordination mechanisms; and strong political support (Wibowo and Alfen, 2014). These identified success factors in Malaysia and Indonesia are similar to those factors identified in other countries mentioned earlier. But in Indonesia, an irrevocable contract as a success factor is distinct from other countries reported. This may be due to the situation of contract administration within the country. These factors are identified in the developing countries and show that the public sector needs to make more contributions to the development of the PPP projects. 
Table 1: PPP success factors from literature review

\begin{tabular}{|c|c|c|c|c|c|c|c|c|c|c|c|c|c|c|c|}
\hline & 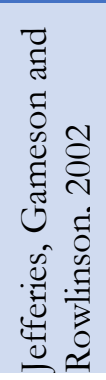 & 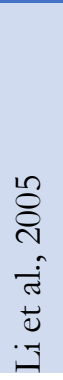 & 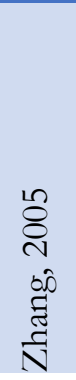 & 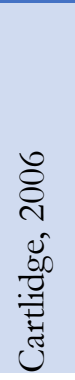 & 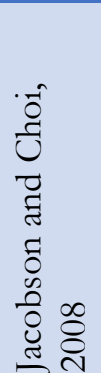 & 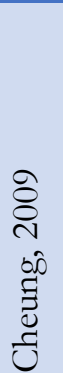 & 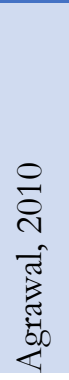 & 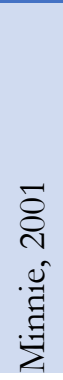 & 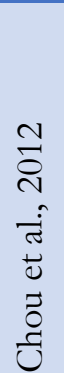 & 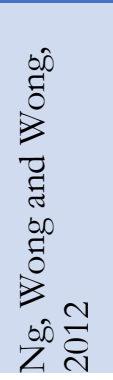 & 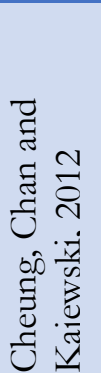 & 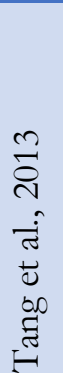 & 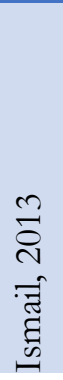 & 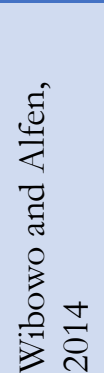 & 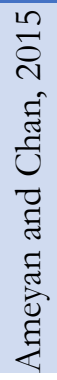 \\
\hline Strong private consortium & $x^{-1}$ & $\times$ & $\times$ & & & $x$ & & & & $\times$ & & & & & $x$ \\
\hline An efficient approval process & $\times$ & & & & & & & & & & & & & & \\
\hline Innovation in the financial methods of consortium & $\times$ & & & & & & & & & & & & & & \\
\hline Appropriate risk allocation and sharing & & $x$ & $x$ & & & $x$ & & & & & & & & $x$ & \\
\hline Available financial market & & $\times$ & & & & & & & & & $x$ & & $\times$ & & $x$ \\
\hline Commitment/responsibility of public/private sectors & & $x$ & & $x$ & $x$ & $x$ & & & $x$ & & & & $x$ & & $x$ \\
\hline Thorough and realistic cost/benefit assessment & & $x$ & & & & & & & $x$ & & & & & & \\
\hline Economic viability of the project & & & $x$ & & & & & & & $x$ & & & & & \\
\hline Nature of contractual agreement & & & $x$ & & & & $\times$ & & & & & & & $x$ & \\
\hline Sound financial package & & & $x$ & & & & & & & & & & & & \\
\hline Favourable investment environment & & & $x$ & & & & & & & & & & & & \\
\hline True partnership & & & & $x$ & $x$ & & & & & & & & & & \\
\hline Open communication & & & & $\times$ & $x$ & & & & & & & & & & \\
\hline Favourable legal framework & & & & & & $x$ & & & & & $x$ & & $\times$ & $x$ & $x$ \\
\hline Short construction period & & & & & & & $x$ & & & & & & & & \\
\hline Repayment of the debt & & & & & & & $x$ & & & & & & & & \\
\hline Delivering publicly needed service & & & & & & & & $\times$ & & $\times$ & & & & & \\
\hline Achieving the objectives of the partnership & & & & & & & & $x$ & & & & & & & \\
\hline Sound economic policy & & & & & & & & & & & $x$ & & $\times$ & & \\
\hline Stable macro-economic conditions & & & & & & $x$ & & & & & $x$ & & & & \\
\hline Alignment with government's strategic objectives & & & & & & & & & & $x$ & & $x$ & & & \\
\hline Multi-benefit objectives & & & & & & & & & & & $x$ & & & & \\
\hline Identification and understanding of client/owner requirement & & & & & & & & & & & & $\times$ & & & \\
\hline Clear and precise briefing documents & & & & & & & & & & & & $x$ & & & \\
\hline Feedback from completed projects & & & & & & & & & & & & $x$ & & & \\
\hline Clear defined coordination mechanisms & & & & & & & & & & & & & & $\times$ & \\
\hline Strong political support & & & & & & & & & & & & & & $x$ & $x$ \\
\hline Good governance & & & & & & & & & & & & & $x$ & & \\
\hline
\end{tabular}




\section{Methodology}

For the purpose of this study, a questionnaire survey was used as the main research instrument to obtain relevant data from participants who have played key roles in the implementation of PPP projects from public and private sectors. This was preceded by a rigorous literature review to investigate the current status of the implementation of PPP procurement system. Three interviews were later conducted with experts on PPP projects in order to seek their opinions on the compiled list of PPP CSFs and the suitability of those factors to the local practice. This served as a pilot interview and the interviewees agreed to the relevance of those factors. The profiles of the participants in the pilot interview are shown in Table 2 and their opinions added value to this study. The questionnaire survey was later conducted. This is an effective method of obtaining necessary information and data from a large sample size of the population for quantitative data analysis (Cheung, 2009). A pilot survey was undertaken with twenty (20) respondents before distributing the questionnaires. This stage involved a large number of participants in the PPP procurement system higher than case studies or interview approaches. The questionnaire is divided into two major parts. Part A was on the information about the respondent and part B is on the overall success factors for PPP projects in Nigeria. The respondents were requested to rate the PPP success factors using a five-point Likert scale in part B. The rating systems for the importance of each variable in the questionnaire using the 1 to 5 scale were adopted. Score 1 represents not important, score 2 represents fairly important, score 3 represents important, score 4 represents very important, and score 5 represents highly important.

Non-probability convenience sampling method was used for the survey since the actual number of participants could not be ascertained due to lack of data base that describes the population of participants in the PPP procurement arrangement in Nigeria. Snowball sampling was also used to complement the process where identified participants were persuaded to recommend other key participants to serve as respondents in the data collection process. The respondents included Architects, Quantity Surveyors, Builders, Engineers, Project Managers and other related professionals from the public and private sector. The questionnaires were administered in Lagos (commercial capital of Nigeria), FCT Abuja (administrative capital of Nigeria) and Ogun State in Nigeria. A total of 255 questionnaires were distributed by hand delivery and a total of 184 completed questionnaires were completed and returned. This survey achieved a response rate of 72 per cent and this high response rate was achieved because the researcher was rigorous in making necessary follow up which encouraged the respondents to complete the questionnaires and return them as quickly as possible, although some were collected on later days. Another factor was that the time to answer the questions was very short and this facilitated their quick responses. It takes an average of 10 minutes to complete the questionnaire and a maximum of 20 minutes for each respondent. The following steps were taken to avoid non-response from the potentials respondents: (1) the questions concerning the personal information about the respondents were not included in the questionnaire, (2) hardcopies of the questionnaire and personal deliveries were used to increase the rates of return, and (3) opportunities were given to the respondents that needed more days to answer the questionnaires.

A reliability coefficient test was carried out to determine the degree of reliability of the questionnaire template before it is administered to the respondents. This assesses the internal consistency of items in a questionnaire (Howitt and Cramer, 2008). The critical level for reliability when using Chronbach's alpha is 0.7 and any coefficient below that indicates that the variables are not sufficiently inter-correlated to combine to yield a single latent construct (Fellows and Liu, 2008). In order to achieve reliable results, the attributes that were less than 0.7 were not included in the analysis. Then, an exploratory factor analysis was carried out. Factor analysis is a statistical method used for the identification and grouping of relatively small numbers of variables that have some things in common. It is a multivariate method that shows the relationships among correlated variables difficult to interpret (Fellows and Liu, 2008). Also, it 
is a method that can be used to try to identify patterns in fairly large sets of data with substantial numbers of variables (Howitt and Cramer, 2008). This procedure gives opportunity for making meaningful deductions from the large set of variables in the process of interpreting the outcomes of the questionnaire survey during data analysis and interpretations. Other important measures that are considered in the factor analysis process are Bartlett's test of sphericity, Kaiser-MeyerOlkin Measure (KMO), Measures of Sampling Adequacy (MSA) and factor extraction (Li, 2003). This data analysis technique was used in order to determine representative factors that could indicate other factors to serve as the most important variables that are useful for policy makers and administrators. These factors would help in the decision-making process while the political leaders and private investors could focus on these areas in the PPP project development to serve as a guide.

\section{Results and discussion}

The information on the respondents that participated in the survey is presented in Table 3, Figures $1 \mathrm{a}$ and $1 \mathrm{~b}$. This includes the respondents from public and private sectors. The result shows that 136 respondents were from the public sector and 48 respondents from the private sector representing $74 \%$ and $26 \%$ of the respondents respectively. The indication is that the respondents from the public sector participated more in the survey than the private sector. The observation is that it is much easier to approach the public sector participants than their counterparts in the private organizations. Often, the private sector participants were reluctant to provide information concerning their organizations without due authorization from the management. The ratio of private sector respondents to the variables being measured is considered low for factor analysis and this shows a limitation in this study.

Table 2: Profiles of interviewees for pilot study

\begin{tabular}{|clll|}
\hline Interviewee & Position & Organization & Sector \\
\hline 1 & Head of Unit & Federal Regulatory Agency & Public \\
2 & Director, PPP Unit & Federal Ministry & Public \\
3 & Head of PPP Unit & Special Purpose Vehicle Company & Private \\
\hline
\end{tabular}

Table 3: Number of respondents on survey

\begin{tabular}{|lcc|}
\hline & Frequency & Percentage \\
\hline Public Sector & 136 & 73.9 \\
Private Sector & 48 & 26.1 \\
Total & $\mathbf{1 8 4}$ & $\mathbf{1 0 0 . 0}$ \\
\hline
\end{tabular}

Table 4: Result of data reliability (public sector)

\begin{tabular}{|cc|}
\hline Cronbach's Alpha & No. of Items \\
\hline 0.812 & 13 \\
\hline
\end{tabular}

Table 5: Result of data reliability (private sector)

\begin{tabular}{|cc|}
\hline Cronbach's Alpha & No. of Items \\
\hline 0.781 & 15 \\
\hline
\end{tabular}

Figure 1 a, shows that $29 \%$ of the respondents had between 11 years and 15 years working experience on PPP projects while 32\% of the respondents had between 6 years and 10 years working experience. However, with about $39 \%$ of the respondents having less than 5 years working experiences on PPP projects, the result still shows that a majority of the respondents 
had good working experience (61\%). The result also shows that the majority of respondents were involved in the Infrastructure and Housing sectors with $65 \%$ and $34 \%$ respectively (Figure 1b). These two sectors represent a total of $99 \%$ of the PPP projects by sector while other sectors make up of $1 \%$. A reliability test was then carried out using SPSS before proceeding with the analysis of the survey data.

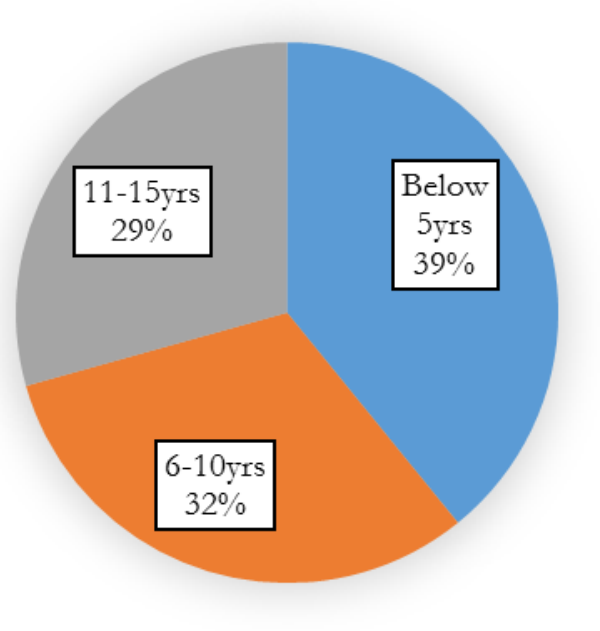

(a)

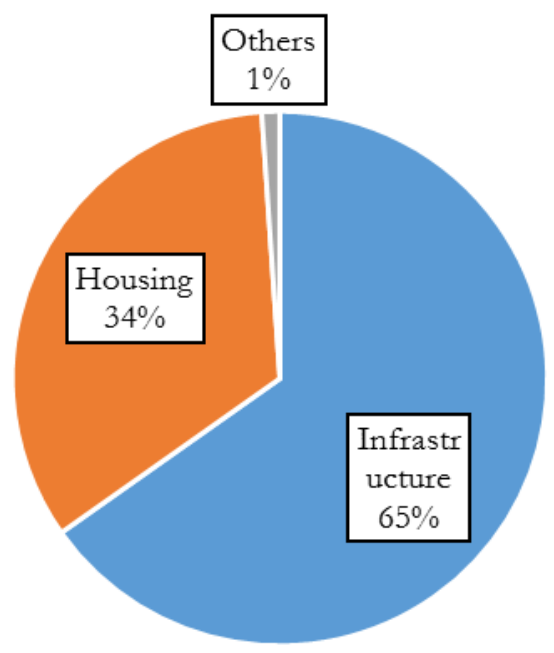

(b)

Figure 1: (a) Participants' experiences on PPP projects; (b) PPP project category

Tables 4 and 5 show the results of the Cronbach's alpha reliability for the PPP success factors. The results show that the data collected are reliable at 0.812 and 0.781 for the public and private sectors respectively (Fellows and Liu, 2008). The use of factor analysis for the success factors of PPP projects was for the purpose of exploring to detect underlying relationships among the factors. This was later described in fewer, more comprehensive factors. This analysis was necessary to determine the few factors that the stakeholders and participants in the implementation process could concentrate upon in order to achieve the objectives of using this procurement method.

Table 6: KMO and Bartlett's test (public sector)

\begin{tabular}{llr}
\hline Kaiser-Meyer-Olkin Measure of Sampling Adequacy. & $\mathbf{0 . 7 4}$ \\
\hline Bartlett's Test of Sphericity & Approx. Chi-Square & 611.055 \\
& df & 78 \\
& Sig. & 0.000 \\
\hline
\end{tabular}

Table 7: KMO and Bartlett's test (private sector)

\begin{tabular}{llr}
\hline Kaiser-Meyer-Olkin Measure of Sampling Adequacy. & $\mathbf{0 . 7 6 7}$ \\
\hline Bartlett's Test of Sphericity & Approx. Chi-Square & 599.812 \\
& df & 105 \\
& Sig. & 0.000 \\
\hline
\end{tabular}


The results of factor analysis of variables that enhance the success of PPP project implementation are listed in Tables 6, 7, 8 and 9. The total variables for both public and private sectors were twenty-eight (28) in number and there were thirteen (13) variables for the public sector and fifteen (15) variables for the private sector. The values of the test statistic for sphericity (Bartlett test of sphericity $=611.055$ ) and (Bartlett test of sphericity $=599.812$ ) for public and private sectors respectively are considered very large. The associated significance levels are small $(\mathrm{p}=0.000)$, suggesting that the population correlation matrix is not an identity matrix. This could be interpreted as the correlation matrix showing all with a significant correlation at the 5\% level. These results show that the principal component analysis could proceed without eliminating any of the variables. The values of KMO statistic are 0.74 and 0.767 for public and private sectors respectively and these are considered satisfactory for the factor analysis. The principal component analysis produced a three-factor solution for the public sector and a four-factor solution for the private sector with eigenvalues greater than 1.000.

Table 8: Rotated factor matrix (loading) of CSFs for public sector

\begin{tabular}{|c|c|c|c|}
\hline & \multicolumn{3}{|c|}{ Component } \\
\hline & 1 & 2 & 3 \\
\hline Multi-benefit objectives & 0.675 & & \\
\hline True partnership & 0.636 & & \\
\hline Alignment with government's strategic objectives & 0.629 & & \\
\hline Clear and precise briefing documents & 0.598 & & \\
\hline Clear defined coordination mechanisms & 0.574 & & \\
\hline Open communication & 0.565 & & \\
\hline An efficient approval process & 0.553 & & \\
\hline Nature of contractual agreement & 0.521 & & \\
\hline Thorough and realistic cost/benefit assessment & 0.521 & & \\
\hline Appropriate risk allocation and sharing & & 0.567 & \\
\hline Sound economic policy & & 0.527 & \\
\hline Achieving the objectives of the partnership & & 0.490 & \\
\hline Feedback from completed projects & & & 0.599 \\
\hline
\end{tabular}

Table 8 shows the three component factors for the public sector which accounted for $60 \%$ of the total variance from the thirteen variables. This is the factor grouping based on varimax rotation and the loading on each factor exceeds 0.40 . Each variable is weighted heavily on only one of the factors. The three principal factors are hereby interpreted as follows:

\section{Factor 1 - Leadership focus}

This principal factor accounts for $30.44 \%$ of the total variance of PPP success factors. This factor is composed of nine sub-factors; multi-benefit objectives, true partnership, alignment with government's strategic objectives, clear and precise briefing documents, clear defined coordination mechanisms, open communication, an efficient approval process, nature of the contractual agreement, and thorough and realistic cost/benefit assessment. This result shows that the public sector must be able to provide the needed leadership role in the implementation of PPP projects. They should focus while considering the objectives of utilizing PPP procurement, on making the partnership work and aligning the implementation process with the government's objectives. These three components have high loadings (significance 0.675, 0.636 and 0.629 respectively). Also, the public sector must assemble the team that would produce clear and precise briefing documents (significance 0.598 ) in order to give a good direction to the 
private sector participants. In an attempt to give good direction, the public sector should identify clear defined coordination mechanisms (significance 0.574 ) and provide open communication (significance 0.565 ) with the private sector and the general public. An efficient approval process (significance 0.553), nature of contractual agreement (significance 0.521), and thorough and realistic cost/benefit assessment (significance 0.521) are the last three factors that are also considered important for the public sector in the implementation of PPP projects. These factors are considered very important for the successful implementation of public projects using PPP procurement method.

\section{Factor 2 - Risk allocation and economic policy}

This principal factor accounts for $12.60 \%$ of the total variance of PPP success factors. This factor is composed of three sub-factors; appropriate risk allocation and sharing (significance 0.567), sound economic policy (significance 0.527) and achieving the objectives of the partnership (significance 0.490). The management of the risk associated with PPP projects is very important to the success of the project. This is confirmed by earlier studies ((Li et al., 2005, Zhang, 2005; Cheung, 2009; Wibowo and Alfen, 2014). Therefore, the public sector should ensure that the appropriate risk is allocated to the party best suited to manage such risk. Another important factor for the success of PPP projects is the availability of sound economic policy by the political leaders. This factor gives direction to the development of the economy and provides an environment conducive to the implementation of PPP projects. Thus, if such an environment is available, then, the objectives of the partnership could be achieved. These objectives could be regarded as effective developments of infrastructure for the public sector while enabling the maximization of profit for the private sector partners.

\section{Factor 3 - Projects Feedback}

This principal factor accounts for $16.68 \%$ of the total variance of PPP success factors. This factor is composed of one sub-factor as feedback from completed projects. The value of its significance is 0.599 . This result shows that the process of reviewing and getting feedback from completed PPP projects would provide adequate information for future implementation of such projects. The identified challenges could then be avoided while success factors could be noted and incorporated into future projects by the public sector participants.

Table 9 shows the four component factors of the private sector which accounted for $54 \%$ of the total variance from the fifteen variables. This is the factor grouping based on varimax rotation and the loading on each factor exceeds 0.40 . Each variable is weighted heavily on only one of the factors. The four principal factors are interpreted below.

\section{Factor 1 - Favourable socio-economic factors}

This principal factor accounts for $26.54 \%$ of the total variance of PPP success factors. This factor is composed of eleven sub-factors; stable macro-economic conditions (significance 0.662), favourable investment environment (significance 0.651), commitment and responsibility of public/private sectors (significance 0.650), innovation in the financial methods of consortium (significance 0.618), available financial market (significance 0.580), economic viability of the project (significance 0.551), strong private consortium (significance 0.548), favourable legal framework (significance 0.544), repayment of the debt (significance 0.484), identification and understanding of client/owner requirement (significance 0.481) and sound financial package (significance 0.473 ). This result shows that the implementation of PPP projects would only be successful in a favourable investment environment. This favourable environment needs to be complimented with the commitment of the public and private sectors' participants. However, 
the review of PPP projects implementation in other countries, showed that the successful deliveries of PPP projects in countries like United Kingdom, Australia, Singapore, Hong Kong, Malaysia and South Africa (Li et al., 2005; Tang et al., 2013; Hwang, Zhao and Gay, 2013; Ng, Wong and Wong, 2012; Ismail, 2013; and Minnie, 2011 respectively) were due to the conducive investment environments. The international and local investors were attracted to those countries mentioned above because they knew that their rights were going to be protected under the law and that they could easily get justice from the courts of law in cases where their rights are denied. This is seriously lacking in Nigeria where the contract provisions are badly being breached and court orders are frequently disobeyed.

Table 9: Rotated factor matrix (loading) of CSFs for private sector

\begin{tabular}{|c|c|c|c|c|}
\hline & \multicolumn{4}{|c|}{ Component } \\
\hline & 1 & 2 & 3 & 4 \\
\hline Stable macro-economic conditions & 0.662 & & & \\
\hline Favourable investment environment & 0.651 & & & \\
\hline $\begin{array}{l}\text { Commitment and responsibility of public/private } \\
\text { sectors }\end{array}$ & 0.650 & & & \\
\hline Innovation in the financial methods of consortium & 0.618 & & & \\
\hline Available financial market & 0.580 & & & \\
\hline Economic viability of the project & 0.551 & & & \\
\hline Strong private consortium & 0.548 & & & \\
\hline Favourable legal framework & 0.544 & & & \\
\hline Repayment of the debt & 0.484 & & & \\
\hline $\begin{array}{l}\text { Identification and understanding of client/owner } \\
\text { requirement }\end{array}$ & 0.481 & & & \\
\hline Sound financial package & 0.473 & & & \\
\hline Good governance & & 0.511 & & \\
\hline Strong political support & & 0.463 & & \\
\hline Short construction period & & & 0.831 & \\
\hline Delivering publicly needed service & & & & 0.528 \\
\hline
\end{tabular}

\section{Factor 2-Good governance and political support}

This principal factor accounts for $10.55 \%$ of the total variance of PPP success factors. This factor is composed of two sub-factors; good governance, and strong political support with significance values of 0.511 and 0.463 . This result shows the importance of the political leaders in creating policies to drive the development of infrastructure and public services through the utilization of PPP procurement method. In addition, an earlier study showed the very importance of political support, and this is found to be the top critical success factor in the implementation of PPP projects in the United Arab Emirates (UAE) (Dulaimi et al., 2010). The study also concluded that this is relevant to most Middle East countries where governments' influences are strong. In the implementation of PPP as procurement systems, the support of political leaders and citizens, are vital to the success of the arrangement, while lack of political support could affect the commitments from the public sector to the projects and public opinion against PPP could affect the development of those projects. Moreover, social support should assist the process and allow smooth management of the facilities in terms of payment of tolls and other commitments from the public. Therefore, the political leaders are expected to do a thorough assessment of the cost and associated benefits of the projects, to determine the outcome of the process. 


\section{Factor 3 - Short construction period}

This principal factor accounts for $8.78 \%$ of the total variance of PPP success factors. This factor is composed of one sub-factor; short construction period with significance value 0.831 . The factor has the highest loading of the success factors for public and private sectors. This shows that this factor is very important to the success of the private investors in PPP projects implementation. This factor is one of the three most important PPP success factors in India (Agrawal, 2010). India and Nigeria are both developing countries. The results of the two researches show common outcomes while the social and environmental factors are identical. Hence, this result is relevant to the developing countries and this factor is important for a successful business project. It is necessary that this factor is achievable in the implementation of PPP projects. If the project is delivered on time, the project cost associated with project management is reduced and the investors could recoup the funds invested in the project.

\section{Factor 4 - Delivering publicly needed service}

This principal factor accounts for $7.92 \%$ of the total variance of PPP success factors. This factor is composed of one sub-factor, which is delivering publicly needed service with a significance value of 0.528 . This result shows that the provision of public services that could meet the expectations of direct users of such facilities is very important for public acceptability. If the project is accepted by the public, the users would be willing to pay for the use of the facilities and the investors would be able to maximize their profits. This situation will provide a win-win result which is an important objective of PPP procurement system.

\section{Success factors model for PPP project implementation}

The result of the factor analysis was able to identify the principal factors that are critical to the delivery of PPP project within the study area. The principal success factors identified for the public sector participants were leadership focus, risk allocation and economic policy, and projects feedback, whereas the four principal factors identified for the private investors in the implementation of PPP projects are favourable socio-economic factors, good governance and political support, short construction period, and delivering publicly needed service. These factors are considered the most important and, if utilized, would improve the implementation of PPP procurement method while acting as a catalyst for the development of infrastructure in the country. These principal factors summarized the success factors required for the implementation of PPP projects in the study. The public sector serves as the client or owner of the projects under PPP arrangement, so, the likelihood of success would be enhanced when the public sector participants take up the leadership role to ensure that all issues relating the projects are resolved as quick as possible. As the leader and owner of the project, the public sector should create avenues for parties to benefit from the arrangement.

Figure 2 shows the public and private sectors' success factors model that incorporates the seven main factors considered the most important to the successful delivery of PPP project in Nigeria. These three principal factors (projects feedback, leadership focus, and risk allocation and economic policy) are those that contribute to the PPP project success with the participation of the public sector. These factors provide a good foundation for project development during the project planning and procurement stages. If these principal factors are included in the implementation of PPP projects, the success of the project is assured. However, the other four principal factors (good governance and political support, short construction period, favourable socio-economic factors, and delivering publicly needed service) are those that ensure the success of project development through private sector participation. These four main factors must be available during the project construction and operation stages of the PPP project. The success factors model in Figure 3 explains that the PPP project implementation process must be 
supported by the identified main factors in order to produce an efficient and successful public project. This result shows that the seven identified factors are critical to the process of delivering PPP projects in Nigeria.

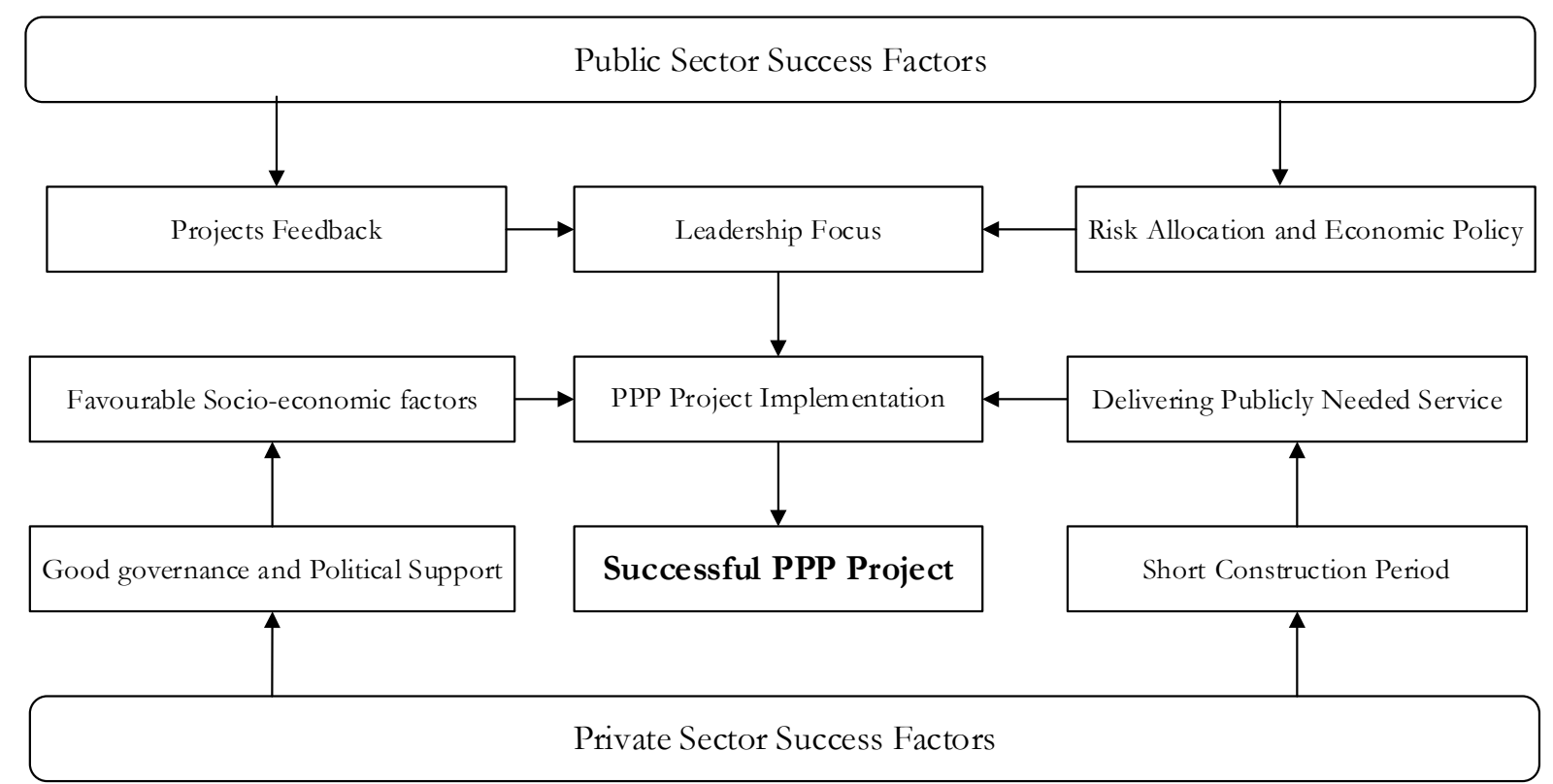

Figure 2: Public and private sectors' success factors model for PPP projects

The first success factor for public sector is the 'projects feedback'. This factor is expected to assist the public sector participants in understanding the challenges and be able to address them in order to improve future projects. 'Risk allocation' is another factor considered important at the planning stage of the project and this helps in allocating the risks to the party in the better position to manage them. Also, a sound 'economic policy' of the government gives direction to the public sector participants while the 'leadership focus' of the public sector helps the whole process in achieving the objectives of the PPP project implementation. On the other hand, the private sector participants need 'good governance and political support' to succeed in the implementation of PPP projects while 'favourable socio-economic factors' provide enabling environment for the investors. Furthermore, the short construction period' and the 'delivering publicly needed service' are factors that help the private investors to achieve their objectives of participating and investing in PPP projects. Profit maximization and organization's reputation are some of the objectives of the private sectors' participation in the project. Thus, if the private sectors could achieve their aims of participating, the whole PPP project implementation process should succeed. This creates avenues for a win-win situation for the PPP procurement system.

\section{Conclusions}

The successful implementation of PPP projects is crucial to the development of social and economic infrastructures. The result of the factor analysis was able to identify the seven most important factors that are critical to a successful PPP project. These factors form the cardinal areas that governments should focus on for the improvement and development of the system to use PPP procurement method, especially in developing countries. This helps to achieve benefits for the adoption of private financing for the delivery of public projects. Moreover, the availability of a matured political environment would encourage participants in the implementation process, while a favourable socio-economic environment provides an enabling setting for growth and development. Despite the benefits, one of the limitations of this study is 
that the outcome of this process could only be applicable in developing countries with similar experience regarding the implementation of PPP projects. Furthermore, nearly forty percent of the respondents of this study had limited experience working on PPP projects. Therefore, any future study is expected to consider additional respondents with work experience of more than five years and the proportion of total variance should be for at least $75 \%$ for the factor analysis. Its result should be compared with the outcome of this study. Subsequently, the test-retest reliability and alternate form reliability methods for an external consistency reliability assessment of survey that were not utilized could be considered in the future study. Nevertheless, the results would assist foreign participants, especially those from developed countries, to understand the factors that promote investments in the system. The participants could be better informed on the factors that are likely to help in the delivery and implementation of PPP projects in the region.

\section{References}

Agrawal, R., 2010. Successful Delivery of Public-Private Partnerships for Infrastructure Development. PhD. Jaypee Institute of Information Technology, India.

Ameyan, E. E. and Chan, A.P.C., 2015. Implementing PPP Water Supply Projects in Ghana. African Journal of Applied Research, 1(1), pp.453-69.

Awodele, O.A., Ogunlana, S.O. and Akinradewo, O.F., 2012. Evaluation of Public Private Partnership as alternative procurement route for infrastructure development: case of Nigeria mega city. In: Laryea, S., Agyepong, S.A., Leiringer, R. and Hughes, W., eds. Procs $4^{\text {th }}$ West Africa Built Environment Research (WABER) Conference. Abuja, Nigeria, 24-26 July 2012. pp.329-44.

Bullen, C.V. and Rockart, J.F., 1981. A primer on critical success factors. Centre for Information Systems Research, Sloan School of Management, Massachusetts Institute of Technology. Available at: http://hdl.handle.net/1721.1/1988.

Cartlidge, D., 2006. Public Private Partnerships in Construction. 1st ed. London: Taylor and Francis Group.

Cheung, E., 2009. Developing a best practice framework for implementing public private partnerships in Hong Kong. PhD. Queensland University of Technology, Australia.

Cheung, E., Chan, A. P.C. and Kajewski, S., 2012. Factors contributing to successful public private partnership projects: Comparing Hong Kong with Australia and the United Kingdom. Journal of Facilities Management, 10(1), pp.45-58. doi: http://dx.doi.org/10.1108/14725961211200397

Chien, H., 2014. Identify the Critical Success Factors of Business Management in Taiwanese Veterans Home. Universal Journal of Management 2(2), pp.49-63.

Chou, J., Tseng, H. P., Lin, C. and Yeh, C.,2012. Critical Factors and Risk Allocation for PPP Policy: Comparison between HSR and General Infrastructure Projects. Transport Policy, 22, pp.36-48. doi: http://dx.doi.org/10.1016/i.tranpol.2012.05.009

Chua, D. K.H., Kog, Y.C. and Loh, P.K., 1999. Critical success factors for different project objectives. Journal of Construction Engineering and Management, 125(3), pp.142-50. doi: http://dx.doi.org/10.1061/(ASCE)07339364(1999)125:3(142)

Dulaimi, M. F., Alhashemi, M., Ling, F.Y.Y. and Kumaraswamy, M., 2010. The Execution of Public-Private Partnership Projects in the UAE. Construction Management and Economics, 28, pp.393-402. doi: http://dx.doi.org/10.1080/01446191003702492

Fellows, R. and Liu, A., 2008. Research Methods for Construction. 1st ed. Oxford: Blackwell Publishing Ltd.

Global Finance, 2013 Country Report: Nigeria. [online] Available at: www.gfmag.com/gdp-data-country-reports/207nigeria-gdp- country- report.html [Accessed 14 April 2013].

Hartmann, A., Davies, A. and Frederiksen, L., 2010. Learning to deliver service-enhanced public infrastructure: balancing contractual and relational capabilities. Construction Management and Economics, 28(11), pp.1165-175. doi: http://dx.doi.org/10.1080/01446193.2010.521942

Howitt, D. and Cramer, D., 2008. Introduction to SPSS in Psychology: For Version 16 and Earlier. 4th ed. England: Pearson.

Hwang, B., Zhao, X. and Gay, M. J. S., 2013. Public Private Partnership Projects in Singapore: Factors, Critical Risks and Preferred Risk Allocation from the Perspective of Contractors. International Journal of Project Management, 31(3), pp.424-33. doi: http://dx.doi.org/10.1016/j.ijproman.2012.08.003

Ismail, S., 2013. Critical success factors of public private partnership (PPP) implementation in Malaysia. Asia-Pacific Journal of Business Administration, 5(1), pp.6-19. doi: http://dx.doi.org/10.1108/17574321311304503

Jacobson, C. and Choi, S. O., 2008. Success factors: public works and public-private partnerships. International Journal of Public Sector Management, 21(6), pp637-57. doi: http://dx.doi.org/10.1108/09513550810896514 
Jefferies, M., Gameson, R. and Rowlinson, S., 2002. Critical Success Factors of the BOOT Procurement System: Reflection from the Stadium Australia Case Study. Engineering, Construction and Architectural Management, 9(4), pp.352-61. doi: http://dx.doi.org/10.1108/eb021230

Kwak, Y. H., Chih, Y.Y. and Ibbs, C.W., 2009. Towards a Comprehensive Understanding of Public Private Partnerships for Infrastructure Development. California Management Review, 51(2), pp.51-77. doi: http://dx.doi.org/10.2307/41166480

Li, B., 2003. Risk. Management of Construction Public Private Partnership Projects. PhD. Glasgow Caledonian University.

Li, B., Akintoye, A., Edwards, P.J. and Hardcastle, C., 2005. Critical success factors for PPP/PFI projects in the UK construction industry. Construction Management and Economics, 23(5), pp.459-71. doi: http://dx.doi.org/10.1080/01446190500041537

Minnie, J. A., 2011. Critical Success Factors for Public-Private Partnerships in South Africa. PhD. Stellenbosch University, South Africa.

Ng, S. T., Wong, Y.M.W. and Wong, J.M.W., 2012. Factors influencing the success of PPP at feasibility stage - A tripartite comparison study in Hong Kong. Habitat International, 36, pp.423-32. doi: http://dx.doi.org/10.1016/i.habitatint.2012.02.002

RICS, 2011. The future of Private Finance Initiative and Public Private Partnership. RICS Research Report June 2011. London: RICS.

Sanvido, V., Grobler, F., Parfitt, K., Guvenis, M. and Coyle, M., 1992. Critical success factors for construction projects. Journal of Construction Engineering and Management, 118(1), pp.94-111. doi: http://dx.doi.org/10.1061/(ASCE)0733-9364(1992)118:1(94)

Syuhaida, I. and Aminah, M.Y., 2009. The provision of infrastructure via Private Finance Initiative. Theoretical and empirical Researches in Urban Management. Special Number 15/April 2009: Urban Issues in Asia, pp.76-86.

Tang, L., Shen, Q., Skitmore, M. and Cheng, E. W.L., 2013. Ranked Critical Factors in PPP Briefings. Journal of Management in Engineering, 29(2), pp.164-71. doi: http://dx.doi.org/10.1061/(ASCE)ME.1943-5479.0000131

The Economist, 2014. Africa's New Number One. The economist of 12 ${ }^{\text {th }}$ April 2014. [online] Available at: http://www.economist.com/news/leaders/21600685-nigerias-suddenly-supersized-economy-indeed-wonder-soare-its-still-huge [Accessed 10 April 2016].

Udechukwu, C.E., 2012. Sustainable development of infrastructure in Lagos-Nigeria through public private partnership. International Journal of Research in Management, Economics and Commerce, 2(6), pp.30-47.

Wibowo, A. and Alfen, H. W., 2014. Identifying macro-environmental critical success factors and key areas for improvement to promote public-private partnerships in infrastructure. Engineering, Construction and Architectural Management, 21(4), pp.383-402. doi: http://dx.doi.org/10.1108/ECAM-08-2013-0078

World Economic Forum, 2012. The Global Competitiveness Report (2012-2013): Insight Report. Full Data Edition. In: Schwab, K., ed. Geneva: World Economic Forum.

Zhang, X., 2005. Critical Success Factors for Public-Private Partnerships in Infrastructure Development. Journal of Construction Engineering and Management, 131(1), pp.3-14. doi: http://dx.doi.org/10.1061/(ASCE)07339364(2005)131:1(71) and http://dx.doi.org/10.1061/(ASCE)0733-9364(2005)131:1(3) 